\title{
Anti-PD-L1 Monoclonal Antibody
}

National Cancer Institute

\section{Source}

National Cancer Institute. Anti-PD-L1 Monoclonal Antibody. NCI Thesaurus. Code C128057.

A monoclonal antibody directed ag ainst programmed death-lig and 1 (PD-L1; CD274). 